\title{
EXISTENCE OF SOLUTIONS TO NONLINEAR LEGENDRE BOUNDARY VALUE PROBLEMS
}

\author{
BENJAMIN FREEDMAN AND JEsús RODRÍGUEZ
}

\begin{abstract}
In this paper, we consider nonlinearly perturbed Legendre differential equations subject to the usual boundary conditions. For such problems we establish sufficient conditions for the existence of solutions and in some cases we provide a qualitative description of solutions depending on a parameter. The results presented depend on the size and limiting behavior of the nonlinearities.
\end{abstract}

Mathematics subject classification (2010): 34A34, 34B15, 47H09, 47H10, $47 \mathrm{~J} 07$.

Keywords and phrases: Boundary value problems, ordinary differential equation, nonlinear equations, fixed-point theorems.

\section{REFERENCES}

[1] B. AHMAD, J. J. NiETo, Existence of solutions for nonlocal boundary value problems of higher-order nonlinear fractional differential equations, Abstract and Applied Analysis 2009 (2009).

[2] A. BOUCHERIF, Second-order boundary value problems with integral boundary conditions, Nonlinear Anal., 70, (2009) 364-371.

[3] P. Canuto, M. Y. Huss aini, A. Quateroni, T. A. Zang, Spectral Methods in Fluid Dynamics, Springer-Verlag, Berlin Heidelberg 1988.

[4] X. Chen, Z. Du, Existence of positive periodic solutions for a neutral delay predator-prey model with Hassell-Varley type functional response and impulse, Qual. Theory Dyn. Syst., (2018), 67-80.

[5] S. Chow, J. K. HALE, Methods of Bifurcation Theory, Spring, Berlin, 1982.

[6] P. DRÁBEK, Landesman-Lazer type condition and nonlinearities with linear growth, Czechoslovak Math J., 40 (1990) 70-86.

[7] P. Drábek, J. Milota, Methods of Nonlinear Analysis: Applications to Differential Equations, Birkhaüser Verlag AG, Basel, 2007.

[8] Z. I. DU, J. YIN, A second order differential equation with generalized Sturm-Liouville integral conditions at resonance, Filomat, 287 (2014) 1437-1444.

[9] D. L. ETHERIDGe, J. RodrígueZ, Scalar discrete nonlinear two-point boundary value problems, Journal of Difference Equations and Applications, 4, 2 (1998), 127-144.

[10] B. Freedman, J. Rodríguez, On the Solvability of Nonlinear Differential Equations Subject to Generalized Boundary Conditions, Differential Equations and Applications, 10, 3 (2018), 317-327.

[11] S. Holland, Applied Analysis by the Hilbert Space Method: An Introduction with Applications to the Wave, Heat, and Schrödinger Equations, Dover Publications, Dover Ed edition, 2007.

[12] S. LANG, Real and Functional Analysis, vol. 142 of Graduate Texts in Mathematics, Springer-Verlag, New York, 1993.

[13] A. C. LAZER, D. F. LEACH, Bounded perturbations of forced harmonic oscillators at resonance, Ann. Mat. Pure Appl., 82 (1969) 49-68.

[14] D. MARONCELli, J. RodRÍGUEZ, Existence theory for nonlinear Sturm-Liouville problems with nonlocal boundary conditions, Differential Equations and Applications 10, 2 (2018), 147-161.

[15] D. Maroncelli, J. Rodríguez, Periodic behaviour of nonlinear, second-order discrete dynamical systems, Journal of Difference Equations and Applications 22, 2 (2016), 280-294.

[16] J. RODRÍGUEZ, Galerkin's method for ordinary differential equations subject to generalized nonlinear boundary conditions, J. Differential Equations, 97, 1 (1992) 112-136. 
[17] J. Rodríguez, Nonlinear discrete Sturm-Liouville problems, J. Math Anal. Appl., 308, 1 (2005) 380-391.

[18] J. Rodríguez, Z. Abernathy, On the Solvability of Nonlinear Sturm-Liouville Problems, Journal of Mathematical Analysis and Applications, 387, 1 (2012), 310-319.

[19] J. Rodríguez, A. J. SuAREZ, On nonlinear perturbations of Sturm-Liouville problems in discrete and continuous settings, Differential Equations and Applications 8, 3 (2016), 319-334.

[20] J. RodríGuez, A. J. SUAREZ, Existence of solutions to nonlinear boundary value problems, Differential Equations and Applications 9, 1 (2017), 1-11.

[21] J. RodrígueZ, D. SWEet, Projection methods for nonlinear boundary value problems, Journal of Differential Equations 58, (1985), 282-293.

[22] J. RODRÍGUEZ, P. TAYLOR, Scalar discrete nonlinear multipoint boundary value problems, Journal of Mathematical Analysis and Applications 330, 2 (2007), 876-890.

[23] J. F. RodríGUEZ, Existence theory for nonlinear eigenvalue problems, Appl. Anal., 87 (2008) 293 301.

[24] M. URABE, Galerkin's procedure for nonlinear periodic systems, Archive for Rational Mechanics and Analysis, 20, (1965) 120-152. 